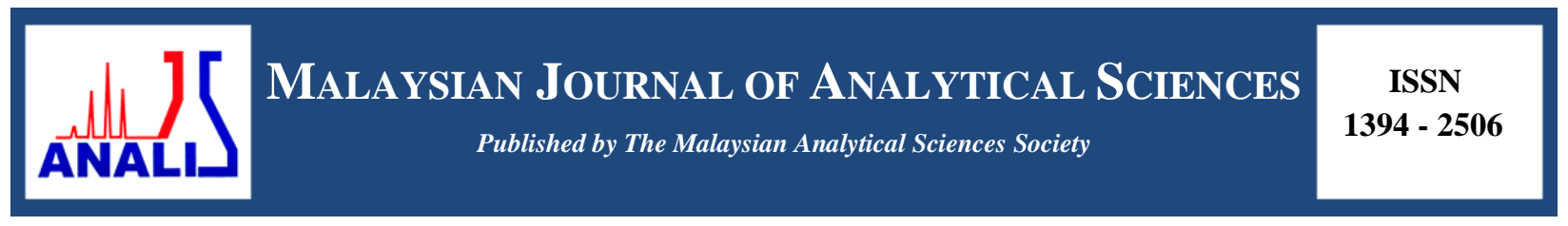

\title{
COMPARATIVE COLUMN STUDIES OF CHEMICALLY MODIFIED ION EXCHANGE RESIN WITH AGGLOMERATED ADSORBENTS FOR FLUORIDE REMOVAL
}

\author{
(Kajian Perbandingan Turus Resin Penukaran Ion Terubahsuai dengan Penjerap Teraglomerat \\ bagi Penyingkiran Fluorida)
}

\author{
Sivasankari Chandasekaran ${ }^{1} *$ and Arulanantham Arthanas ${ }^{2}$ \\ ${ }^{1}$ Department of Chemistry, \\ Government College of Technology, Coimbatore 641 013, India \\ ${ }^{2}$ Department of Chemistry, \\ Sri Sakthi Institute of Engineering and Technology, Coimbatore 641 062, India
}

*Corresponding author: sivasankarigct@gmail.com

Received: 24 February 2015; Accepted: 27 October 2015

\begin{abstract}
The present study is aimed to prepare three different granular adsorbents and applying on fluoride removal in column operations. Commercially available powdered adsorbents activated alumina (PAA) and tri-calcium phosphate (PTCP) is agglomerated to obtain granular polymer agglomerated alumina (GPAA) and granular polymer agglomerated tri-calcium phosphate (GTCP). Agglomeration was carried out using powdered adsorbents with neutral and non-toxic polymer Poly (vinyl acetate) to granular form of 20 - 50 mesh size. Plain Amberlite IRA 400 anion exchange resin (PR) was chemically modified (CMR) through phosphorylation by alum impregnation and investigated for fluoride removal as a third adsorbent. Column studies were carried out using $1.5 \mathrm{~cm}$ diameter columns to find out the suitability of the material for large scale applications. Solutions containing 5 $\mathrm{mg} \mathrm{L}^{-1}$ of fluoride adjusted to $\mathrm{pH} 7.0$ were allowed to percolate through the column at known flow rates. Under optimum conditions of flow rate $10 \mathrm{~mL} \mathrm{~min}^{-1}$ and bed height of $31 \mathrm{~cm}(25 \mathrm{~g})$ of GPAA, $36 \mathrm{~cm}(20 \mathrm{~g})$ of GTCP and $42 \mathrm{~cm}(20 \mathrm{~g})$ of CMR respectively. The amount of fluoride removed were $1.948 \mathrm{mg} \mathrm{g}^{-1}, 2.1005 \mathrm{mg} \mathrm{g}^{-1}$, and $2.3325 \mathrm{mg} \mathrm{g}^{-1}$ of the respective adsorbent. The effects of co-existing anions were also studied in column experiments. Column regeneration studies were also carried out for all the adsorbents with $\mathrm{Al}_{2}\left(\mathrm{SO}_{4}\right)_{3}$ solutions. The cyclic regeneration experiments indicated that all the three adsorbents could be completely regenerated and used for repeated cycle. Ground water sample was collected from a village in Dharmapuri district of South India. The defluoridation capacity of the wet resin $\left(6.80 \mathrm{mg} \mathrm{g}^{-1}\right)$ was found to be three times more than dried resin. CMR potentially can be the best adsorbent for fluoride removal.
\end{abstract}

Keywords: defluoridation, agglomeration, poly vinyl acetate, granular adsorbents, column studies

\begin{abstract}
Abstrak
Matlamat kajian ini adalah untuk menyediakan tiga penjerap berbutir yang berbeza dan diaplikasikan untuk penyingkiran fluorida dalam operasi turus. Penjerap komersial serbuk teraktif alumina (PPT) dan tri-kalsium fosfat (PTCP) digumpalkan untuk mendapatkan polimer berbutir alumina (GPAA) dan polimer berbutir tri-kalsium fosfat (GTCP). Penggumpalan telah dijalankan dengan menggunakan penjerap serbuk poli polimer (vinil asetat) neutral dan tidak toksik kepada bentuk berbutir dari 20-50 saiz sirat. Amberlit kosong IRA 400 anion resin pertukaran (PR), telah diubahsuai secara kimia (CMR) melalui kaedah pemfosforilan mengunakan impregnasi alum, dan diuji untuk penyingkiran fluorida sebagai penjerap ketiga. Kajian turus telah dilakukan dengan menggunakan $1.5 \mathrm{~cm}$ diameter turus bagi mengetahui kesesuaian bahan untuk aplikasi skala besar. Larutan fluorida yang berpekatan $5 \mathrm{mg} \mathrm{L}^{-1}$ dan $\mathrm{pH} 7.0$ dibiarkan meresap melalui turus pada kadar aliran yang telah dikenalpasti. Di bawah keadaan
\end{abstract}




\section{Chandasekaran \& Arthanas: COMPARATIVE COLUMN STUDIES OF CHEMICALLY MODIFIED ION EXCHANGE RESIN WITH AGGLOMERATED ADSORBENTS FOR FLUORIDE REMOVAL}

optimum, kadar aliran ialah $10 \mathrm{~mL} \mathrm{~min}^{-1}$ dan ketinggian dasar masing - masing ialah $31 \mathrm{~cm} \mathrm{(25} \mathrm{g)} \mathrm{GPAA,} 36 \mathrm{~cm}(20 \mathrm{~g})$ GTCP

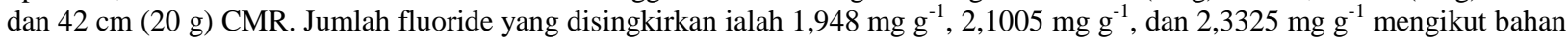
penjerap masing-masing. Kesan anion sedia ada juga dikaji dalam eksperimen turus. Kajian pengunaan semula turus turut dijalankan untuk semua penjerap menggunakan larutan $\mathrm{Al}_{2}\left(\mathrm{SO}_{4}\right)_{3}$. Eksperimen penghasilan semula kitaran menunjukkan bahawa ketiga-tiga penjerap boleh dihasilkan semula sepenuhnya dan digunakan untuk kitaran berulang. Sampel air bawah tanah telah dikumpulkan dari sebuah kampung di daerah Dharmapuri, India Selatan. Kapasiti penyingkiran fluorida oleh resin basah (6.80 $\left.\mathrm{mg} \mathrm{g}^{-1}\right)$ telah didapati tiga kali lebih tinggi daripada resin kering. CMR berpotensi menjadi penjerap yang terbaik untuk penyingkiran fluorida.

Kata kunci: penyingkiran fluorida, penggumpalan, poli vinil asetat, penjerap berbutir, kajian turus

\section{Introduction}

It is well known that trace elements are essential and beneficial to organism in minute concentrations, as they play a significant role in many metabolic processes. But they would be toxic when their concentrations exceed the permissible levels. Fluoride, a typical trace element is distributed in rock, soil and water. The safe limit of fluoride in drinking water level in between $0.7 \mathrm{mg} \mathrm{L}^{-1}$ to $1.5 \mathrm{mg} \mathrm{L}^{-1}$ but harmful once it exceeds to $1.5 \mathrm{mg} \mathrm{L}^{-1}$ which is the World Health Organization limit being followed in most of the nation's [1]. Fluoride in minute quantity is an essential component for normal mineralization of bones and formation of dental enamel [2]. However its excessive intake may result in slow, progressive crippling scourge known as fluorosis.

Defluoridation is the only practicable option to overcome the problem of excessive fluoride in drinking water, where alternate source is not available. Adsorption technique retains a major place in defluoridation research and practice because of its greater accessibility and lower cost. Several adsorbent materials have been tried in the past to find out an efficient and economical defluoridating agent. Activated carbons, low cost waste materials, alum impregnated materials, mineral based adsorbents, activated alumina, tri-calcium phosphate and ion-exchange resins etc. are different adsorbent materials reported. Activated alumina is regarded as an excellent and widely used adsorbent for defluoridation. Tri-calcium phosphate is another adsorbent that has gel structure and better characteristics than that of activated alumina [3]. Both the adsorbents show increased adsorption capacity in the powder form as the surface area and consequently more number of active sites are exposed.

However, the adsorbents in the powdered form are not suitable for continuous column operations as they produce pressure drop. It was decided to agglomerate the above powdered adsorbents into granular form so that the adsorbents could be profitably used in column operations without loss in their capacity for fluoride removal. A suitable method could be agglomeration using a cheap, readily available and non-toxic polymer. Polyvinyl acetate was found to be a better choice as it is soluble in simple organic solvents but insoluble in aqueous medium. Apart from the preparation of granular adsorbents from powdered activated alumina and tri-calcium phosphate by agglomeration it was also decided to prepare a superior adsorbent for fluoride removal and compare its fluoride removal capacity with other two adsorbents. The better choice would be to chemically modify readily available granular ion exchange polymer resin so that its physical characteristics could be retained, simultaneously improving its capacity, $\mathrm{pH}$ tolerance and selectivity towards fluoride in the presence of common anions.

\section{Defluoridation materials}

\section{Materials and Methods}

Commercially available acidic powdered activated alumina (PAA) and powdered tri-calcium phosphate (PTCP), and solid poly vinyl acetate were used for agglomeration. Granular polymer agglomerated alumina (GPAA) was prepared by thoroughly mixing one part by weight of Poly (vinyl acetate) in minimum quantity of acetone and 2.5 parts by weight of finely powdered activated alumina till a semi-solid mass was obtained. Large volume of water was poured into it in one lot with vigorous stirring. It was found that this approach was effective to cover the aluminium oxide powder by polymer. The agglomerated product was separated and pressed between two glass plates into a sheet of $2-3 \mathrm{~mm}$ thickness. The sheet was washed with water dried overnight at room temperature and then cut to 20 - 50 mesh size for detailed examination. Polymer agglomerated granular tri-calcium phosphate (GTCP) was also prepared by the same method used for the preparation GPAA. Chemically modified resin (CMR) was prepared by phosphorylation of Amberlite IRA 400 anion exchange resin followed by alum impregnation. 
Initially the resin was washed with distilled water and dried at room temperature for few hours. An amount of $50 \mathrm{~g}$ of this resin was treated with $100 \mathrm{~mL}$ of concentrated phosphoric acid and heated in the hot air oven at a temperature of $160 \pm 1^{\circ} \mathrm{C}$ for 12 hours. The material removed from the oven was washed with distilled water to remove excess acid. The sample was then soaked in $1 \%$ aluminium sulphate solution; the $\mathrm{pH}$ was adjusted to $3.0-$ 3.5 and left soaked for 12 hours. At the end of this period, the resin was separated, washed to remove excess of $\mathrm{Al}$ (III) ions and then dried at $100 \pm 5^{\circ} \mathrm{C}$.

\section{Reagents and standard solutions}

Fluoride stock solution was prepared by dissolving $2.21 \mathrm{~g}$ pure of anhydrous sodium fluoride (Sd fine-chemicals Ltd) in $1000 \mathrm{~mL}$ distilled water in a plastic volumetric flask and all working solutions were prepared by appropriate dilution of stock solution with distilled water. The Total Ionic Strength Adjustment Buffer (TISAB) was prepared according to a recommended procedure [4]. Fluoride ion concentration was estimated by Orion Ion meter (EA 920 model).

\section{Column experiments}

Powder activated alumina (PAA) and powder tri-calcium phosphate (PTCP) developed pressure drops in the course of column experiments. To overcome the problem of pressure drop, GPAA, GTCP were used and their fluoride removal behaviors were compared with that of CMR. Column experiments were carried out using $70 \mathrm{~cm}$ long and $1.5 \mathrm{~cm}$ diameter. Teflon column packed with the materials under study, to a predetermined height. As the fluoride concentration of untreated drinking water usually lies below $5 \mathrm{mg} \mathrm{L}^{-1}$ and $\mathrm{pH}$ remains in the range of 6.5 to 8.5 , solutions containing $5 \mathrm{mg} \mathrm{L}^{-1}$ of fluoride adjusted to $\mathrm{pH} 7.0$ were allowed to percolate through the column at known flow rates. Each batch of the effluent $(1000 \mathrm{~mL})$ was separately collected and analyzed for fluoride content using Orion ion meter. Percolation of fluoride solution was stopped when the concentration of fluoride in the effluent exceeded the permissible limit of $1.5 \mathrm{mg} \mathrm{L}^{-1 .}$ In order to find out the optimum flow rate, the fluoride solutions were allowed to flow through the column of constant bed height at separate flow rates from 7, 10, 12 and $15 \mathrm{~mL} \mathrm{~min}^{-1}$. The effluent was analyzed until breakthrough $\left(1.5 \mathrm{mg} \mathrm{L}^{-1}\right)$ occurred and the capacity of the adsorbents in each instance was established. In order to find out the optimum bed height for maximum removal of fluoride, experiments were conducted using varying amount of each adsorbents to fill up the column to different bed heights, and percolating the fluoride solution at optimum flow rate.

\section{Effects of co-existing anions}

The effect of co-existing anions $\left(\mathrm{Cl}^{-}, \mathrm{SO}_{4}{ }^{2-}, \mathrm{HCO}_{3}{ }^{-}\right.$and $\left.\mathrm{PO}_{4}{ }^{3-}\right)$ on fluoride removal efficiency of the adsorbents were also studied using column experiments with fluoride solution of $5 \mathrm{mg} \mathrm{L}^{-1}$ and varying anions concentration from $50 \mathrm{mg} \mathrm{L}^{-1}$ to $200 \mathrm{mg} \mathrm{L}^{-1}$. All the experiments were conducted using GPAA, GTCP and CMR with already established optimum flow rates and bed heights. Each batch of the effluents $(1000 \mathrm{~mL})$ were separately collected and analyzed for fluoride content.

\section{Column regeneration studies}

Regeneration of the column was done by percolating sufficient volume of aluminium sulphate solution of predetermined concentrations through the exhausted bed of adsorbents. In order to find out the efficiency of the adsorbents after regeneration, experiments were performed using columns containing $25 \mathrm{~g}$ of GPAA, $20 \mathrm{~g}$ each of GTCP and CMR. Fluoride solution containing $5 \mathrm{mg} \mathrm{L}^{-1}$ was allowed to percolate through the column at $10 \mathrm{~mL} \mathrm{~min}^{-1}$ till the break point. The volume of aluminium sulphate solution used was measured in terms of number of bed volumes. Since the desorption of fluoride from the adsorbent bed is a slow process, the exhausted column was washed with three bed volumes of aluminium sulphate solution at a flow rate of $5 \mathrm{~mL} \mathrm{~min}^{-1}$ and one bed volume of aluminium sulphate solution was left in contact with the adsorbent for 12 hours. The solution was then drained out and the column was washed thoroughly with water to render it free from aluminium (III). The capacity of the regenerated adsorbents was determined after conducting the defluoridation experiments under optimum conditions. Attrition loss of all the three adsorbents was found out by the usual procedure [5].

\section{Application of CMR for defluoridation of real water sample}

In order to find out the suitability of the adsorbent for large scale applications for removal of fluoride from ground water, experiments were conducted using $20 \mathrm{~g}$ of wet CMR. The water used for the experimental purposes was 


\section{Chandasekaran \& Arthanas: COMPARATIVE COLUMN STUDIES OF CHEMICALLY MODIFIED ION EXCHANGE RESIN WITH AGGLOMERATED ADSORBENTS FOR FLUORIDE REMOVAL}

collected from Dharmapuri district of Tamilnadu in South India. Water sample was analyzed for its characteristics as presented in Table 1. The capacity of CMR under wet condition for real water sample was determined as per the procedure discussed in column studies.

Table 1. Characteristics of the real water sample

\begin{tabular}{ll}
\hline $\begin{array}{l}\text { Characteristics of } \\
\text { the water sample }\end{array}$ & $\begin{array}{l}\text { Concentration }\left(\mathbf{m g ~ L}^{\mathbf{1}}\right) \\
\text { except } \mathbf{~ p H}\end{array}$ \\
\hline $\mathrm{pH}$ & 7.98 \\
Alkalinity & 96 as $\mathrm{CaCo}_{3}$ equivalent \\
Total hardness & $161 \mathrm{as} \mathrm{CaCo}_{3}$ equivalent \\
Chloride & 109 \\
Sulphate & 42 \\
Fluoride & 3.3 \\
\hline
\end{tabular}

\section{Influence of flow rate}

\section{Results and Discussion}

The capacities at various flow rates obtained for GPAA, GTCP and CMR are summarized in Table 2. It was found that the fluoride removal is almost constant $1.694 \pm 0.03 \mathrm{mg} \mathrm{g}^{-1}$ for GPAA, $1.86 \pm 0.02 \mathrm{mg} \mathrm{g}^{-1}$ for GTCP and $2.36 \pm$ $0.03 \mathrm{mg} \mathrm{g}^{-1}$ for CMR up to flow rates $12 \mathrm{~mL} \mathrm{~min}^{-1}$. At a higher flow rate of $15 \mathrm{~mL} \mathrm{~min}^{-1}$ the fluoride removal was found to be drastically reduced to $1.165 \mathrm{mg} \mathrm{g}^{-1}, 1.506 \mathrm{mg} \mathrm{g}^{-1}$ and $1.9175 \mathrm{mg} \mathrm{g}^{-1}$ for the respective adsorbents. It may be concluded that at lower flow rates the fluoride ions have sufficient time to reach the reaction sites and get adsorbed. At higher flow rates there is a reduced interaction between the fluoride and the adsorbent and hence there was a rapid fall in the capacity of adsorbents for fluoride. Therefore, in all subsequent experiments, a flow rate of 10 $\mathrm{mL} / \mathrm{min}$ was employed for all the three adsorbents.

Table 2. The capacities of various flow rates obtained for GPAA, GTCP and CMR

\begin{tabular}{lccccc}
\hline Adsorbents & $\begin{array}{c}\text { Fixed bed heights } \\
(\mathbf{c m})\end{array}$ & \multicolumn{4}{c}{ Capacities at various flow rate $\left(\mathbf{m g ~ g}^{\mathbf{- 1}}\right)$} \\
\cline { 3 - 6 } & & $\begin{array}{c}\mathbf{7} \mathbf{~ m L} \\
\left(\mathbf{m i n}^{-1}\right)\end{array}$ & $\begin{array}{c}\mathbf{1 0 ~} \mathbf{~ m L} \\
\left(\mathbf{m i n}^{-1}\right)\end{array}$ & $\begin{array}{c}\mathbf{1 2} \mathbf{~ m L} \\
\left(\mathbf{m i n}^{-1}\right)\end{array}$ & $\begin{array}{c}\mathbf{1 5} \mathbf{~ m L} \\
\left(\mathbf{m i n}^{-1}\right)\end{array}$ \\
\hline GPAA & 25 & 1.697 & 1.694 & 1.693 & 1.165 \\
GTCP & 27 & 1.868 & 1.868 & 1.846 & 1.507 \\
CMR & 42 & 2.390 & 2.333 & 2.328 & 1.918 \\
\hline
\end{tabular}

\section{Influence of bed height}

The bed height is another important parameter that determines the capacity of any adsorbent. The effect of variation of fluoride removal capacity by unit weight of all the three adsorbents, at the fixed flow rate of $10 \mathrm{~mL} \mathrm{~min}^{-1}$ was summarized in Table 3.

It was found that the minimum bed heights for maximum fluoride removal, in terms of unit weight of adsorbents are $31 \mathrm{~cm}(25 \mathrm{~g})$ for GPAA $36 \mathrm{~cm}(20 \mathrm{~g})$ for GTCP and $42 \mathrm{~cm}(20 \mathrm{~g})$ for CMR. Therefore the fluoride removal capacities by unit weight of all the three adsorbents can be reported as $1.95 \mathrm{mg} \mathrm{g}^{-1}$ for GPAA, $2.10 \mathrm{mg} \mathrm{g}^{-1}$ for GTCP and $2.33 \mathrm{mg} \mathrm{g}^{-1}$ for CMR. The results obtained are summarized in Table 4. Therefore the optimum bed heights maintained for further experiments are $31 \mathrm{~cm}$ for GPAA, $36 \mathrm{~cm}$ for GTCP and $42 \mathrm{~cm}$ for CMR. 
Table 3. The capacities of various bed heights obtained for GPAA, GTCP and CMR

\begin{tabular}{lccc}
\hline Adsorbents & $\begin{array}{c}\text { Fed flow rate } \\
\left(\mathbf{m L ~ m i n}^{-1}\right)\end{array}$ & $\begin{array}{c}\text { Various bed height } \\
(\mathbf{c m})\end{array}$ & $\begin{array}{c}\text { Adsorption capacities } \\
\left(\mathbf{m g ~ g}^{-\mathbf{1}}\right)\end{array}$ \\
\hline GPAA & 10 & $19(15 \mathrm{~g})$ & 1.309 \\
& & $25(20 \mathrm{~g})$ & 1.695 \\
& & $31(25 \mathrm{~g})$ & 1.948 \\
& & $37(30 \mathrm{~g})$ & 1.950 \\
$\mathrm{GTCP}$ & 10 & $18(10 \mathrm{~g})$ & 1.848 \\
& & $27(15 \mathrm{~g})$ & 1.868 \\
& & $36(20 \mathrm{~g})$ & 2.099 \\
& & $45(25 \mathrm{~g})$ & 2.140 \\
$\mathrm{CMR}$ & 10 & $21(10 \mathrm{~g})$ & 1.896 \\
& & $31.5(15 \mathrm{~g})$ & 2.185 \\
& & $42.0(20 \mathrm{~g})$ & 2.333 \\
& & $52.5(25 \mathrm{~g})$ & 2.331 \\
\hline
\end{tabular}

Table 4. The results obtained for GPAA, GTCP and CMR

\begin{tabular}{lccc}
\hline Adsorbents & $\begin{array}{c}\text { Flow rate } \\
\left(\mathbf{m L}^{-\mathbf{1}}\right)\end{array}$ & $\begin{array}{c}\text { Bed heights } \\
(\mathbf{c m})\end{array}$ & $\begin{array}{c}\text { Capacities of the adsorbents } \\
\left(\mathbf{m g ~ g}^{-\mathbf{1}}\right)\end{array}$ \\
\hline GPAA & 10 & 31 & 1.948 \\
GTCP & 10 & 36 & 2.099 \\
CMR & 10 & 42 & 2.333 \\
\hline
\end{tabular}

\section{Effect of common anions on the removal of fluoride on GPAA, GTCP and CMR}

From the results (Table 5), it was observed that the presence of chloride has no significant effect on the efficiency of the adsorbents up to $200 \mathrm{mg} \mathrm{L}^{-1}$. The presence of sulphate found to affect the efficiency of the adsorbents to a small extent. For GPAA the fluoride removal capacity was found to be reduced to $95.2 \%, 87.5 \%, 66.5 \%$ and $45.7 \%$ and in case of GTCP it was found to be reduced to $99.6 \%, 92.7 \%, 78.6 \%$ and $67.3 \%$ for respectively for $50 \mathrm{mg} \mathrm{L}^{-}$ ${ }^{1}, 100 \mathrm{mg} \mathrm{L}^{-1}, 150 \mathrm{mg} \mathrm{L}^{-1}$ and $200 \mathrm{mg} \mathrm{L}^{-1}$ of $\mathrm{SO}_{4}{ }^{2-}$ ion concentration. Presence of sulphate has no significant effect on fluoride removal capacity of CMR within the tested concentration range of $50 \mathrm{mg} \mathrm{L}^{-1}$ to $200 \mathrm{mg} \mathrm{L}^{-1}$. The bicarbonate interference showed significant reduction of fluoride removal due to the change in $\mathrm{pH}$ as well as the competing effect of this co-ion for the active sites of the adsorbents [6]. For the presence of bicarbonate concentration $50 \mathrm{mg} \mathrm{L}^{-1}, 100 \mathrm{mg} \mathrm{L}^{-1}, 150 \mathrm{mg} \mathrm{L}^{-1}$ and $200 \mathrm{mg} \mathrm{L}^{-1}$ the fluoride removal capacity was found to be reduced to $77.7 \%, 67.5 \%, 48.7 \%$ and $38.6 \%$ respectively for GPAA and $80.2 \%, 44.7 \%, 32.8 \%$ and $22.4 \%$ respectively for GTCP.

The presence of bicarbonate has no significant effect on the fluoride removal capacity of CMR up to a concentration of $200 \mathrm{mg} \mathrm{L}^{-1}$. The other ion $\mathrm{PO}_{4}{ }^{3-}$ interferes with the sorption of fluoride at the elevated concentrations due to the preferential adsorption of $\mathrm{PO}_{4}{ }^{3-}$ over activated alumina and tri-calcium phosphate. The fluoride removal efficiency of GPAA decreased to $69.9 \%, 44.8 \%, 26.4 \%$ and $18.4 \%$ for $50 \mathrm{mg} \mathrm{L}^{-1}, 100 \mathrm{mg} \mathrm{L}^{-1}, 150 \mathrm{mg} \mathrm{L}^{-1}$ and $200 \mathrm{mg} \mathrm{L}^{-1}$ of $\mathrm{PO}_{4}{ }^{3-}$ and for GTCP it was reduced to $79.8 \%, 33.2 \%, 21.1 \%$ and $10.6 \%$. It was noted that, the affinity sequence for anion adsorption on these two adsorbents were in the order $\mathrm{PO}_{4}{ }^{3-}>\mathrm{HCO}_{3}{ }^{-}>\mathrm{SO}_{4}{ }^{2-}>\mathrm{Cl}^{-}$. These results agreed 


\section{Chandasekaran \& Arthanas: COMPARATIVE COLUMN STUDIES OF CHEMICALLY MODIFIED ION \\ EXCHANGE RESIN WITH AGGLOMERATED ADSORBENTS FOR FLUORIDE REMOVAL}

with the reported defluoridation property of activated alumina [7].The presence of ion $\mathrm{PO}_{4}{ }^{3-}$ found to significantly interfere with the adsorption of fluoride over CMR and the fluoride removal efficiency of the adsorbent decreased to $78.4 \%, 60.0 \%, 48.7 \%$ and $39.5 \%$ for $50 \mathrm{mg} \mathrm{L}^{-1}, 100 \mathrm{mg} \mathrm{L}^{-1}, 150 \mathrm{mg} \mathrm{L}^{-1}$ and $200 \mathrm{mg} \mathrm{L}^{-1}$ of $\mathrm{PO}_{4}{ }^{3-}$ ion. From the results it was observed that bicarbonate, sulphate and chloride have no significant effect on fluoride removal capacity of CMR. The phosphate alone showed negative effect on CMR that to a lesser extent compared to the other two adsorbents. These characteristics of CMR suggest the fact that the adsorbent is selective for fluoride removal. Similar types of results were reported by Viswanathan and Meenakshi [8].

Table 5. Effect of common anions on the removal of fluoride on GPAA, GTCP and CMR

\begin{tabular}{|c|c|c|c|c|c|}
\hline \multirow{2}{*}{ Adsorbents } & \multirow{2}{*}{ Anions } & \multicolumn{4}{|c|}{ Concentration of solution (\%) } \\
\hline & & $\begin{array}{c}200 \\
{\operatorname{mg~} L^{-1}}^{2}\end{array}$ & $\begin{array}{c}150 \\
\operatorname{mg~} L^{-1}\end{array}$ & $\begin{array}{c}100 \\
{\operatorname{mg~} L^{-1}}^{2}\end{array}$ & $\begin{array}{c}50 \\
\mathrm{mg} \mathrm{L}^{-1}\end{array}$ \\
\hline GPAA & & & Negligible & & \\
\hline GTCP & $\mathrm{Cl}^{-}$ & & Negligible & & \\
\hline CMR & & & Negligible & & \\
\hline GPAA & & 38.6 & 48.7 & 67.5 & 77.7 \\
\hline GTCP & $\mathrm{SO}_{4}{ }^{2-}$ & 22.4 & 32.8 & 44.7 & 80.2 \\
\hline CMR & & & Negligible & & \\
\hline GPAA & & 38.6 & 48.7 & 67.5 & 77.7 \\
\hline GTCP & $\mathrm{HCO}^{3-}$ & 22.4 & 32.8 & 44.7 & 80.2 \\
\hline CMR & & & Negligible & & \\
\hline GPAA & & 18.4 & 26.4 & 44.8 & 69.9 \\
\hline GTCP & $\mathrm{PO}_{4}{ }^{3-}$ & 10.6 & 21.1 & 33.2 & 79.8 \\
\hline CMR & & 39.5 & 48.7 & 60.0 & 78.4 \\
\hline
\end{tabular}

\section{Column regeneration}

From the column regeneration studies, it was established that $0.25 \%, 0.5 \%$ and $1.0 \%$ solutions of $\mathrm{Al}_{2}\left(\mathrm{SO}_{4}\right)_{3}$ was adequate for the complete regeneration of GPAA, GTCP and CMR. The cyclic defluoridation and subsequent regeneration with aluminium sulphate indicated the potential usefulness of the adsorbents for nearly 8 cycles without significant loss of adsorption capacity. The attrition loss was only around $5 \%$, for GPAA and GTCP, and 4 $\%$ for CMR even after 8 cycles. After 8 cycles, the adsorbents were withdrawn from the column, washed, air dried and weighed to find out its loss. It was noticed that there was no significant loss of all the three adsorbents [9].

It was surprising to note that the fluoride removal capacity of CMR was increased three fold after first regeneration and remained nearly the same, cycle after cycle. Hence, it could be established that the regeneration is not only complete but also has introduced new sites for adsorption of fluoride. The reason for this phenomenon may be due to the replacement of $\gamma$ - $\mathrm{AlOOH}$ present on the dried resin by $-\mathrm{Al}\left(\mathrm{H}_{2} \mathrm{O}\right)_{3}(\mathrm{OH})_{3}$ during regeneration under wet condition. This was also verified by fluoride column adsorption studies using freshly prepared wet CMR without drying. Hence, the following mechanism was proposed.

$$
\begin{aligned}
& -\mathrm{Al}\left(\mathrm{H}_{2} \mathrm{O}\right)_{3}(\mathrm{OH})_{3}+3 \mathrm{~F}^{-} \longrightarrow \mathrm{Al}\left(\mathrm{H}_{2} \mathrm{O}\right)_{3}\left(\mathrm{~F}_{3}\right)+3 \mathrm{OH}^{-} \\
& -\mathrm{Al}\left(\mathrm{H}_{2} \mathrm{O}\right)_{3}(\mathrm{OH})_{3} \text { (under wet condition) } \longrightarrow \mathrm{AlOOH}(\text { Dry })+4 \mathrm{H}_{2} \mathrm{O}
\end{aligned}
$$


$-\mathrm{AlO}-\mathrm{OH}$ (under dry condition) $+\mathrm{F}^{-} \stackrel{105 \pm 5^{\circ} \mathrm{C}}{\longrightarrow}-\mathrm{AlO}-\mathrm{F}+\mathrm{OH}^{-}$

Similar phenomenon has been observed for removal of fluoride using alum impregnated coconut shell carbon in wet condition [10].

\section{Application of CMR}

The defluoridation capacity of the wet resin for real water sample was calculated to be $6.8 \mathrm{mg} \mathrm{g}^{-1}$. From the results, it is evident that the capacity of the adsorbent remained unaffected when applied to ground water containing fluoride. The attrition loss of CMR was found to be only around $4 \%$, even after 8 cycles of adsorption and regeneration.

\section{Conclusion}

Aluminium sulphate solution was found to be the best regenerent for regeneration of all the three adsorbents after saturation with fluoride. Complete regeneration could be achieved with $0.25 \%, 0.5 \%$ and $1.0 \%$ aluminium sulphate solution in the case of GPAA, GTCP and CMR respectively. Column studies have clearly demonstrated that the unit capacity of CMR for adsorption of fluoride was found to be higher than that of other adsorbents GPAA and GTCP. The application of CMR to fluoride bearing waste water showed considerable adsorption capacity. In column regeneration studies, it could be seen that the capacity of GPAA and GTCP for the removal of fluoride remained nearly the same, cycle after cycle showing that the regeneration was complete and the capacity of the adsorbents were retained. The cyclic defluoridation and subsequent regeneration experiments indicated the potential usefulness of the GPAA, GTCP and CMR for nearly 8 cycles without significant loss of sorption capacity. But the fluoride removal capacity of CMR was increased three fold after first regeneration and remained nearly the same, cycle after cycle. It may be pointed out that chemically modified resin (CMR) is superior to other two adsorbents with respect to the removal of fluoride. A ground water sample collected from a village in Dharmapuri district of South India was tested for fluoride removal. The results showed that the defluoridation capacity of the wet resin was $6.80 \mathrm{mg} \mathrm{g}^{-1}$, which leads to the conclusion that CMR could be a better adsorbent for fluoride removal from drinking water.

\section{References}

1. World Health Organization, WHO (1984), Guidelines for Drinking water Quality: Health Criteria and Supporting Information, World Health Organization, Geneva, Switzerland, Vol. II.

2. Bell, M. C. and Ludwig, T. G. (1970). The supply of fluoride to man: ingestion from water, in: Fluorides and Human Health, WHO Monograph Series 59, World Health Organization, Geneva.

3. Adler, H., Klein, G. and Lindsay F. K. (1938). Removal of fluorides from potable water by Tri-calcium phosphate. Industrial and Engineering Chemistry, 30 (2): 163 - 165.

4. Kemer, B., Ozdes, D., Gundogdu, A., Bulut, N., Duran, C. and Soyla, M. (2009). Removal of fluoride ions from aqueous solution by waste mud. Journal of Hazardous Materials, 168: 888 - 894.

5. Ragunathan J. and Krishnamoorthy S. (1984). Studies on resorcinol formaldehyde cationic resins. Journal of Indian Chemical Society, 61(10): 911 - 914.

6. Kagne, S., Jagtap, S., Dhawade, P., Kamble, S. P., Devotta, S. and Rayalu, S. S. (2008). Hydrated cement: A promising adsorbent for the removal of fluoride from aqueous solution. Journal of Hazardous Materials, 154: $88-95$.

7. Tang, Y., Guan, X., Su, T., Gao, N. and Wang, J. (2009). Fluoride adsorption onto activated alumina: Modeling the effects of $\mathrm{pH}$ and some competing ions. Colloids and surfaces A: Physicochemical Engineering Aspects, 337: $33-38$.

8. Viswanathan, N. and Meenakshi S. (2009). Role of metal ion incorporation in ion exchange resin on the selectivity of fluoride. Journal of Hazardous Materials, 162: 920 - 930.

9. Nur, T., Loganathan, P., Nguyen, T. C., Vigneswaran, S., Singh, G and Kandasamy, J. (2014). Batch and column adsorption and desorption of fluoride using hydrous ferric oxide: solution chemistry and modeling. Chemical Engineering Journal, 247: 93 - 102.

10. Arulanantham, A., Ramakrishna, T. V. and Balasubramanian, N. (1992). Studies on fluoride removal by coconut shell carbon. Indian Journal of Environmental Protection, 12(7): 531 - 536. 